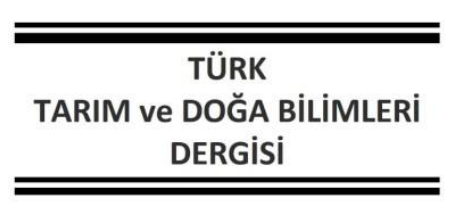

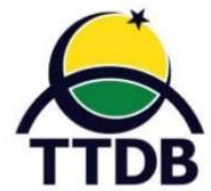

www.dergipark.gov.tr/turkjans

Araştırma Makalesi

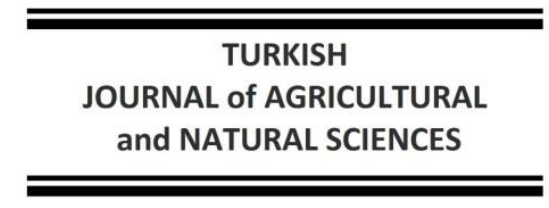

and NATURAL SCIENCES

\title{
Molecular Phylogenetic Analysis of Morkaraman Sheep in Bingol Region
}

\author{
Oğuz AĞYAR ${ }^{1 *}$, Emin ÖZKÖSE², M. Sait EKiNCi², İsmail AKYOL ${ }^{3}$ \\ ${ }^{1}$ Department of Veterinary, Kahta Vocational School, Adiyaman University, Adiyaman, 02440, Turkey \\ 2 Department of Animal Science, Faculty of Agriculture, Kahramanmaras Sutcu Imam University, \\ Kahramanmaraş, 46100, Turkey \\ ${ }^{3}$ Department of Agricultural Biotechnology, Faculty of Agriculture, Ankara University, Ankara, 06110, Turkey \\ *Sorumlu Yazar: oagyar@adiyaman.edu.tr
}

Geliş Tarihi: 04.11.2019, Düzeltme Geliş Tarihi: 09.01.2021, Kabul Tarihi: 15.01.2021

\begin{abstract}
In the present study, we report mitochondrial DNA (mtDNA) 16S rRNA gene sequence analysis of the Morkaraman ewe, (Ovis aries) was investigated. In domestic sheep, the 16S rRNA gene is ca 1574 bp in length. Partial fragment of 536 bp $16 \mathrm{~S}$ rRNA gene of mtDNA was amplified by using designed primers from published data of Sheep sequences derived from National Center for Biotechnology Information (NCBI) web server (ncbi.nlm.nih.gov/NC_001941.1). Homology of the sequences obtained from the present work were performed by using BLAST program at NCBI. Obtained 16S rRNA gene sequences were submited to the GenBank database with accession numbers, KU686952.1, KU686953.1, KU686954.1, KU686955.1, KU686956.1, KU686957.1, KU686958.1, KU686959.1, KU686960.1, KU686961.1 and KU686962.1, respectively. According to nucleotide differences of mtDNA $16 \mathrm{~S}$ rRNA gene region 10 polymorphic regions and 8 haplotypes were detected in Turkish domestic sheep Morkaraman $(n=11)$. The nucleotide composition averages of all the sequences was $32.1 \%$ Adenine (A), 24.2\% Thymine (T), 22.2\% Cytosine (C) and 21.5\% Guanine (G); G+C was 43.7\%. DNA polymorphism based on 16S rRNA gene sequences, haplotype diversity $(H d)$ and nucleotide diversity $(\pi)$ were found to be $0,9273 \pm 0,00442$, and $0,00427 \pm 0,00125$, respectively. Based on gene sequences information, in sheeps, mtDNA haplotypes, the phylogenetic relationship among mtDNA polymorphism, haplotypes and relationship between native sheep breeds and foreign sheep breeds were determined and discussed. Thus, sequence analysis of mitochondrial 16S rRNA gene can be used as a tool for phylogenetic analysis of Morkaraman sheep.
\end{abstract}

Key words: Genetic Diversity, Morkaraman (Ovis aries), Phylogenetic, mtDNA, 16S rRNA

\section{Bingöl Yöresinde Morkaraman Koyunlarının Moleküler Filogenetik Analizi \\ $\overline{0 ̈ z}$ \\ Bu çalışmada, Morkaraman koyunlarının (Ovis aries) filogenetik ilişkileri mitokondriyal DNA (mtDNA) 16S} rRNA gen dizisi analizi ile gerçekleştirilmiştir. Evcil koyunlarda, 16S rRNA geni 1574 baz çifti (bç) uzunluğundadır. Çalışmamızda mtDNA 16S rRNA gen bölgesi hedeflenerek, Ulusal Biyoteknoloji Bilgi Merkezi (NCBI) alınan örnek sekansla (NC_001941.1) tasarlanan primerler ile, 536 bç'lik sekans ürünleri elde edilmiştir. Elde edilen diziler için homoloji araştırması, NCBI'de BLAST kullanılarak yapılmıştır. Çalışma sonunda elde ettiğimiz 16S rRNA gen bölgesi dizi bilgileri GenBank veri tabanına sırası ile bu erişim numaralarıyla yer almaktadır; Sırasıyla KU686952.1, KU686953.1, KU686954.1, KU686955.1, KU686956.1, KU686957.1, KU686958.1, KU686959.1, KU686960.1, KU686961.1 ve KU686962.1. Morkaraman koyun örnekleri ( $n=11)$ üzerinde yapılan analizler sonunda, mtDNA $16 \mathrm{~S}$ rRNA gen bölgesi sekanslarından nükleotit farklılıkları bakımından 10 polimorfik bölge ve 8 haplotip bölge tespit edilmiştir. Tüm dizilerin nükleotit kompozisyon ortalamaları \% 32.1 Adenin (A), \% 24.2 Timin (T), \% 22.2 Sitosin (C) ve \% 21.5 Guanin (G); G + C \% 43.7 olarak bulundu. 16S rRNA gen dizileri, haplotip çeşitliliği $(H d)$ ve nükleotit çeşitliliğine $(\pi)$ dayanan DNA polimorfizmi sırasıyla $0.9273 \pm 0.00442$ ve $0.00427 \pm$ 0.00125 olarak bulunmuştur. Gen dizileri bilgisine dayanarak, koyunlarda, mtDNA haplotipleri, mtDNA 
polimorfizmi, haplotipleri arasındaki filogenetik ilişkiler ile belirlenen yerli ve yabancı koyun ırkları arasındaki filogenetik ilişkileri belirlenmiştir.

Anahtar kelimeler: Filogenetik, Genetik Çeşitlilik, Morkaraman (Ovis aries), mtDNA, 16S rRNA.

\section{Introduction}

One of the important production line of livestock sector in agriculture is sheep breeding. The sheep have a special place in the agricultural structure in terms of combined yield characteristics in animal production, such as milk, meat, leather, fleece, fertilizer and fertility, which are adapted to different geographical regions. The archaeological findings show that sheep were culturally and economically used in social life as an altar in religious ceremonies in some communities (Togan et al., 2013). Moreover, archeological and genetic studies have revealed that the sheep was domesticated in Turkey, in the vicinity of eastern/south-eastern Anatolia. Turkish native sheep (one of them is Morkaraman) are considered as a separate race because they have grown up among themselves for many years (Kurt, 2017; Kul and Ertuğrul, 2010). Morkaraman sheep (Ovis aries), Turkish indigenous breed, are mainly distributed in mountain areas across Eastern Anatolia area at a altitude between 1500 and 2500 $\mathrm{m}$ (Yalçın, 1986). Total number of ovin livestock in 2020 is 55.063.391 in Turkey. Among all the livestock, sheep are 42.712 .580 heads. The proportion of domestic sheep breed is 91.44 percent (TUIK, 2020). Domestic sheep has 54 (2n) of chromosomes, 26 pairs of autosomal chromosomes and 1 pair of sex chromosomes and in addition they have mitochondrial DNA (mtDNA) as well. Sheep mtDNA is a small extrachromosomal genome that is characteristic 16 to $20 \mathrm{~kb}$ in size with 37 genes. Sheep mtDNA is maternal inheritance. Among these 37 genes, 13 proteincoding genes and 22 transfer RNAs (tRNAs), 2 genes encode ribosomal RNAs which $12 \mathrm{~S}$ rRNA and $16 S$ rRNA. In domesticated sheep, the 16S rRNA gene region has a length of $c a 1573$ bp (www.ncbi.nlm.nih.gov). Mitochondrial genes were identified for various species (Saikia et al., 2015; Mane et al., 2013). Especially, mtDNA is commonly used for the study of domesticated species and mtDNA has enable information utility in the study of molecular evolution, population genetic analysis, and identification of relationship for interspecific and intraspecific. (Fan et al., 2016; Naderi et al., 2007). The 16S rRNA gene sequence is widely used as markers for analysis of phylogenetic evolution of sheep and animal species (Sanna et al., 2015; Yan et al., 2019). In addition, subpopulation phylogenetic relationships were determined in populations (Kirikci et al., 2018). Among all molecular techniques, the DNA sequencing has enabled as a widely used method for identifying species. Furthermore, the technique is regarded as one of the most efficient method in terms of detection and definition (Sarri et al., 2014). Considering these facts in view investigations of the phylogenetic analysis of Ovis aries and provides important annotation information for we compared 16S rRNA gene regions sequences from Morkaraman sheep in this study.

\section{Materials and Methods}

The animal material of the present work is Morkaraman sheep which was bred in Bingöl region. Bingöl is located between 41ㅇ - 20 and 39ㅇ - 56을 east longitudes and between 39ㅇ - 31음 and 36 - 28ㅇ North latitudes. The animal material used in this study was obtained from the livestock operations of the provinces of Karlıova, Bingöl city center and Solhan of Bingöl province. Animal welfare was taken into consideration when blood samples were taken from animals by the veterinarian in accordance with The Republic of Turkey Ministry Of Agriculture And Forestry Elazı $\breve{g}$ Veterinary Control Institute directive, for which the ethical license (2011/11-1) of this study was obtained. Genomic DNA was extracted from vena blood (vena jugularis) of eleven native Turkish sheep Morkaraman's using standard commercial Kit (Promega Wizard Genomic DNA Purification Kit A1120) as recommended by the manufacturer. Mitochondrial sequences of sheep were downloaded from the GenBank database and aligned using MEGA 5.1 program (Lasergene software; DNAStar, Inc., Madison, Wisconsin, USA). The GenBank accession number for Ovis aries mtDNA sequences is NC_001941.1. The binding regions of the primers generated from the $16 \mathrm{~S}$ rRNA gene sequence on the Sheep's mtDNA and their expected sequence sizes by PCR analysis are shown in the Table 1. 
Table 1. mtDNA 16S rRNA gene region forward (F) and reverse $(R)$ species-specific primers sets

\begin{tabular}{cccccc}
\hline Primer & Primer Sequence 5' $\rightarrow 3^{\prime}$ & Lenght $(\mathrm{bp})$ & Position & $\operatorname{Tm}\left({ }^{\circ} \mathrm{C}\right)$ & Expected product size (bp) \\
\cline { 1 - 2 } MRK16S(F) & CCAAAATCTCCCACTCTCCAG & 21 & $1106-1127$ & 64.71 & \multirow{2}{*}{$1470-1573$} \\
\cline { 1 - 2 } MRK16S(R) & CTCTTGTCCTTTCGTACTGGG & 21 & $2555-2576$ & 62.52 & \\
\hline
\end{tabular}

Reactions for mtDNA amplification were performed according to Sambrook et al. (1989). PCR reactions were carried out using a Thermal Cycler (Favorgen) and each PCR reaction was consisted of $1 \mu \mathrm{l}$ of template DNA, $1 \mu \mathrm{l}$ of each dNTP, $1 \mu$ of each primer, $1 \mu \mathrm{l}$ of $\mathrm{MgCl} 2,1 \mu \mathrm{l}$ of Taq (5U) DNA polymerase and $4 \mu$ of $10 \mathrm{X}$ buffer and $30 \mu \mathrm{l}$ distilled water in a total volume of $40 \mu \mathrm{l}$. The PCR conditions were conducted as; predenaturation at $95 \circ \mathrm{C}$ for 2 min followed by 35 cycles of $94^{\circ} \mathrm{C}$ for $1 \mathrm{~min}, 60^{\circ} \mathrm{C}$ for $50 \mathrm{sec}, 72^{\circ} \mathrm{C}$ for 1 $\min$ and a one cycle of final extension at $72^{\circ} \mathrm{C}$ for 5 min. After the PCR amplification of $16 \mathrm{~S}$ rRNA encoding gene, 11 individuals were ordered by İontek (Istanbul) company to perform 22 DNA sequencing for both forward and reverse chains. Pairwise sequence alignments were carried out using NCBI-BLAST. Multiple sequence alignments of $16 \mathrm{~S}$ rRNA sequences from Morkaraman Sheep were carried out using CLUSTALW. Total number of regions for populations, number of polymorphic regions $(S)$, haplotype number $(h)$, haplotype diversity $(H d)$, nucleotide diversity $(\pi)$, average number of nucleotide differences $(k)$ and Tajima's $D$ test statistics values were determined using the program of DnaSP 5.0 (Librado and Rozas, 2009). Phylogenetic analyzes of this study were performed by the MEGA 4.0.1 program (Tamura et al., 2007) using the Kimura-2-parameter + Gamma distribution ( $\mathrm{K} 2 \mathrm{P}+\Gamma)$ model according to the Neighbor-Joining (NJ) method (Saitou and Nei, 1987). Bootstrap value of 1000 replicates was used to test the reliability of nodes (Nei and Kumar, 2000). For phylogenetic analysis, Turkey native breeds and gene sequences of previously reported studies with other sheep breeds derived from GenBank (NCBI) were used and optimal phylogenetic trees were obtained.

\section{Results And Discussions}

The 16S rRNA gene regions of the mtDNA of Morkaraman sheep were amplified by PCR techniques using designed primers (Figure 1). The $16 \mathrm{~S}$ rRNA gene region in domestic sheep is $1573 \mathrm{bp}$ in length (https://www.ncbi.nlm.nih.gov/).

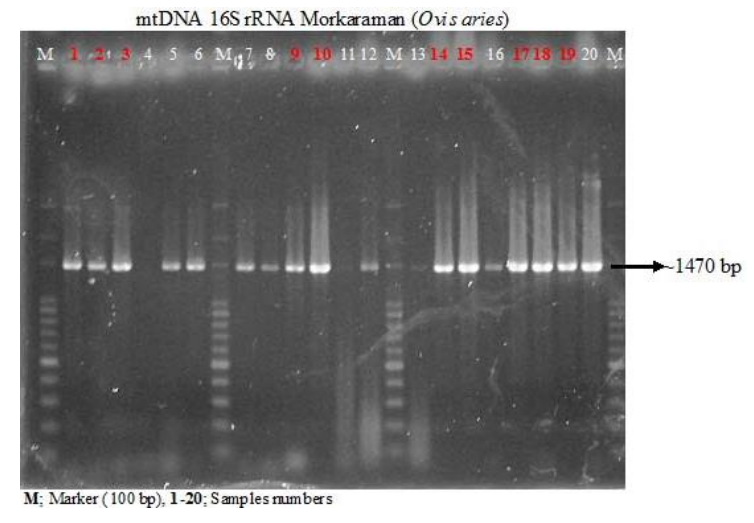

Figure 1. 16S rRNA gene region PCR agarose gel image in Morkaraman sheep.

The PCR products of the 16S rRNA gene region were approximately $1470 \mathrm{bp}$ in length. For sequencing analysis, the DNA samples in wells 1,2 , $3,9,10,14,15,17,18,19$ and 20 were selected in the genomic DNA agarose gel image, respectively. As a result of the arrangement and evaluation of the $1470 \mathrm{bp}$ sequences, a $536 \mathrm{bp}$ segment was sequenced. Additionally, mtDNA 16S rRNA gene sequences belonging to the chromatograms were generated (Figure 2.).

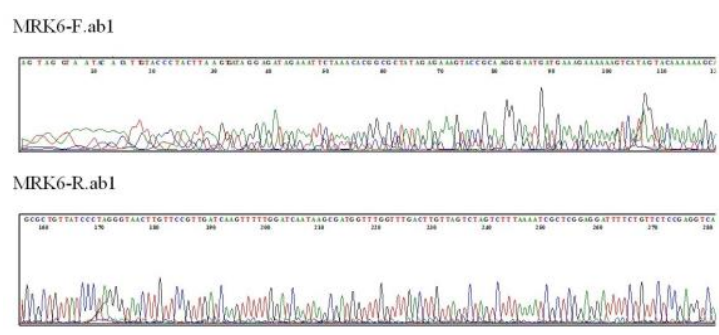

Figure 2. An examplified chromatogram (sample MRK6-F and R) of a section of the mitochondrial DNA 16S rRNA gene of Morkaraman sheep.

In the Morkaraman sheep, 10 polymorphic regions and 8 haplotypes were identified according to their nucleotide sequence differences for $16 \mathrm{~S}$ rRNA gene. It is divided into 8 haplotypes. UPGMA genetic haplotype are shown in tree form (Figure 4.). The haplotype difference $(H d)$ was $0.9273( \pm 0.00442)$ and the nucleotide difference $(\pi)$ was $0.00427( \pm 0.00125)$. Tajima's D value $(-1.40051)$ was negative and statistically significant (Table 2 ). 
Table 2. Basic molecular characteristics of $16 \mathrm{~S}$ rRNA gene region of Morkaraman sheep breed.

\begin{tabular}{ll}
\hline Number of sequence & 536 \\
$\mathrm{G}+\mathrm{C}$ & 0.437 \\
Variable sites $(S)$ & 10 \\
Number of haplotype $(h)$ & 8 \\
Haplotype diversity $(H d)$ & $0.9273 \pm 0.00442$ \\
Nucleotide diversity $(\pi)$ & $0.00427 \pm 0.00125$ \\
$\begin{array}{l}\text { Average number of nucleotide } \\
\text { differences }(k)\end{array}$ & 2.29091 \\
$\begin{array}{l}\text { Tajima's } D \text { test statistics } \\
(P>0.1)\end{array}$ & -1.40051 \\
\hline
\end{tabular}

Findings of current study show the remarkably high haplotype diversity of Morkaraman sheep. Furthermore, these results indicate the effects of the current population expansion with the addition of new mutations in previous generations of morkaraman sheep race. Some of the haplotypes were also found to be partner as stated in tabulated form below (Table 3.).

Table 3. Haplotypes partner to Morkaraman sheep

\begin{tabular}{ccc}
\hline Haplotype & $\begin{array}{c}\text { Number of } \\
\text { haplotype }\end{array}$ & Sample code \\
\hline Hap_5 & 3 & $\begin{array}{c}\text { [MRK05, MRK08, } \\
\text { MRK09] }\end{array}$ \\
\hline Hap_8 & 2 & {$[$ [MRK10, MRK11] } \\
\hline
\end{tabular}

Obtained from mismatch distribution analysis the value $(k=2.29091)$ of the average pairwise differences. The results of Raggedness Statistics ( $r$ ) are determined as 0.1864 .

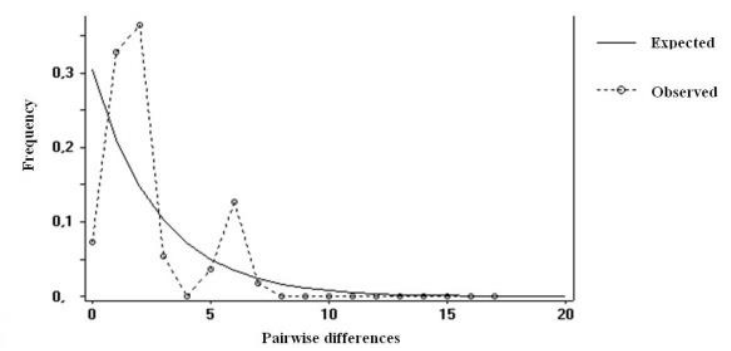

Figure 3. Mismatch distribution of haplotypes.

When the analysis is carried out for 8 haplotypes in this investigation group, multicrowned bell curves were presented in Figure 3. German native sheep of the Merinolandschaf race was used as a reference sequence (NC_001941.1) in the comparison of the genetic difference of the haplotypes found for Morkaraman in current work (Hiendleder, 1998). Morkaraman haplotypes were analyzed in order to see their genetic distances to each other and to compare the genetic differences between them with reference gene sequencing (NC_001941.1). As a result of analysis, it was found that the genetic distance was the highest between MRK06 and MRKO1 with the highest value of 0.01325 . On the other hand, the maximum genetic distance between the reference sequence and MRK06 was found to be 0.00944 . (Table 4.).

Table 4. Genetic distance between Morkaraman haplotypes and the German native sheep of the Merinolandschaf (RefSeq).

\begin{tabular}{|c|c|c|c|c|c|c|c|c|c|c|c|}
\hline 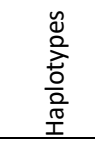 & 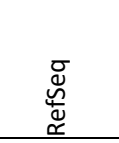 & $\frac{\vec{\rho}}{\frac{\vec{\rho}}{\Sigma}}$ & 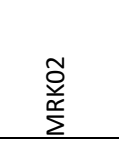 & $\begin{array}{l}\frac{n}{2} \\
\frac{\tilde{c}}{\Sigma}\end{array}$ & 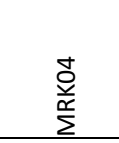 & 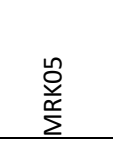 & $\begin{array}{l}\mathscr{D} \\
\frac{\stackrel{\Sigma}{c}}{\Sigma}\end{array}$ & $\begin{array}{l}\hat{\hat{0}} \\
\frac{\stackrel{\underline{v}}{\Sigma}}{\Sigma}\end{array}$ & $\begin{array}{l}\frac{\infty}{0} \\
\frac{\stackrel{x}{x}}{\Sigma}\end{array}$ & $\begin{array}{l}\frac{8}{2} \\
\frac{\text { con }}{\Sigma}\end{array}$ & $\begin{array}{l}\stackrel{ }{\vec{y}} \\
\frac{\underline{\alpha}}{\Sigma}\end{array}$ \\
\hline \multicolumn{12}{|l|}{ RefSeq } \\
\hline MRK01 & 0.00374 & & & & & & & & & & \\
\hline MRK02 & 0.00187 & 0.00563 & & & & & & & & & \\
\hline MRK03 & 0.00187 & 0.00563 & 0.00375 & & & & & & & & \\
\hline MRKO4 & 0.00187 & 0.00187 & 0.00375 & 0.00374 & & & & & & & \\
\hline MRK05 & 0.00187 & 0.00187 & 0.00375 & 0.00374 & 0.00374 & & & & & & \\
\hline MRK06 & 0.00944 & 0.01325 & 0.01135 & 0.01134 & 0.01134 & 0.01134 & & & & & \\
\hline MRK07 & 0.00187 & 0.00563 & 0.00375 & 0.00375 & 0.00375 & 0.00375 & 0.01135 & & & & \\
\hline MRK08 & 0.00187 & 0.00187 & 0.00375 & 0.00374 & 0.00374 & 0.00000 & 0.01134 & 0.00375 & & & \\
\hline MRK09 & 0.00187 & 0.00187 & 0.00375 & 0.00374 & 0.00374 & 0.00000 & 0.01134 & 0.00375 & 0.00000 & & \\
\hline MRK10 & 0.00000 & 0.00374 & 0.00187 & 0.00187 & 0.00187 & 0.00187 & 0.00944 & 0.00187 & 0.00187 & 0.00187 & \\
\hline MRK11 & 0.00000 & 0.00374 & 0.00187 & 0.00187 & 0.00187 & 0.00187 & 0.00944 & 0.00187 & 0.00187 & 0.00187 & 0.00000 \\
\hline
\end{tabular}


Because of the limited DNA polymorphism of the phylogenetic tree formed according to the sequences of the 16S rRNA gene and the genetic distance between the lower value is the number of haplotypes was preferred UPGMA tree.

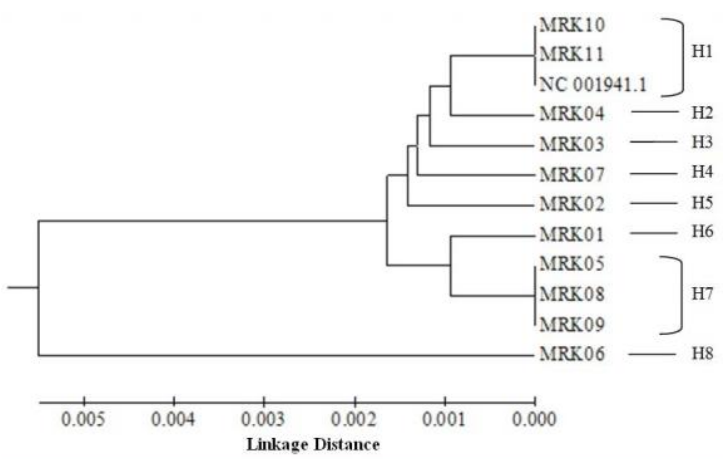

Figure 4. The UPGMA phylogenetic tree constructed for the mtDNA 16S rRNA gene sequences for 11 Morkaraman sheep together with the reference sequence (NC 001941.1). The tree was drawn to scale and individual substitutions are indicated (H1-H8; Haplotypes group).

Differences in the nucleotide sequences of the haplotypes when the resulting DNA sequences were compared. Merinolandschaf German native sheep (NC 001941.1) was taken for the basis for comparison as outgroup control. The first sequence on the table belongs to the reference sequence (NC_001941.1) (Table 5.). Nucleotide substitutions in the 10 polymorphic regions are observed to be in the form of transitions.

Table 5. The haplotypes determined according to the 16S rRNA gene region for Morkaraman Sheep when comparing to the reference sequence (NCBI: NC_001941.1)

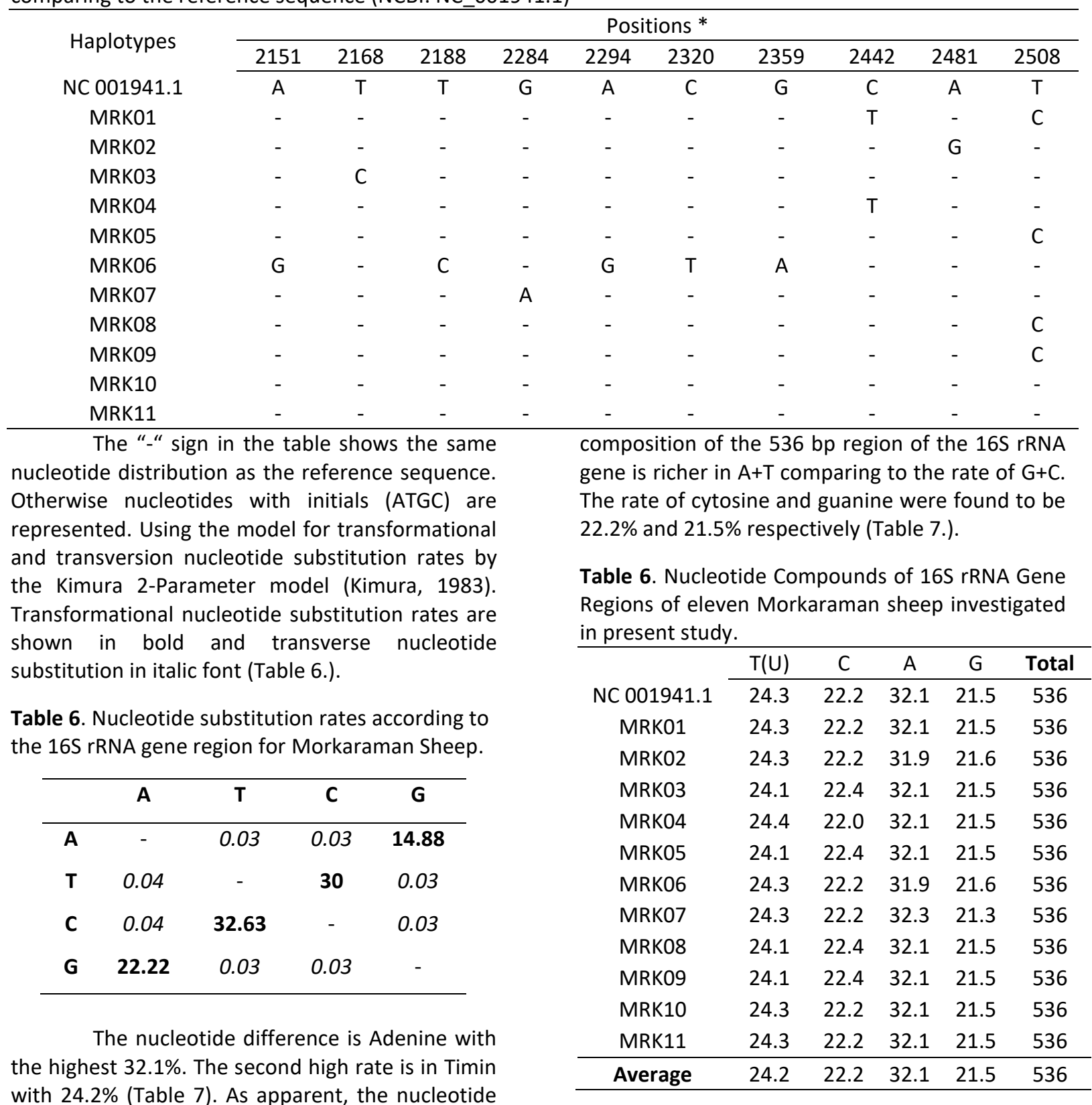


Kimura 2 parameters (K2P) model and Neighbor-Joining (NJ) method was performed to form the phylogenic trees showing the phylogenetic relations between the varieties (Figure 5.).

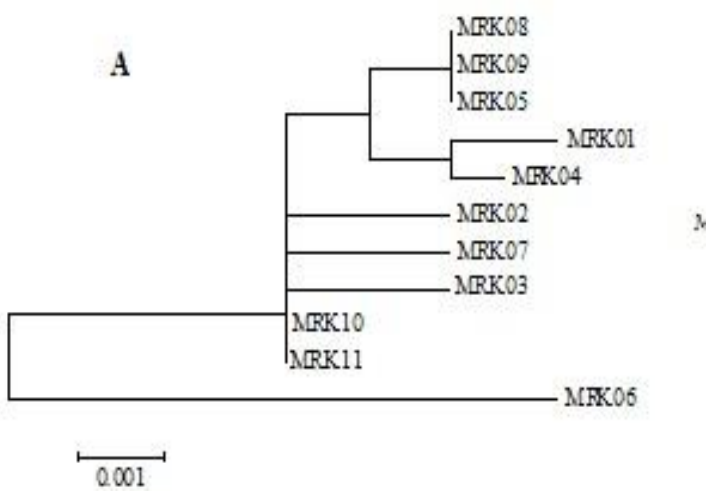

Figure 5. The UPGMA phylogenetic tree constructed for the mtDNA 16S rRNA gene sequences for 11 Morkaraman sheep.

MRKO4 and MRKO1 varieties are tightly linked to each other as shown in the phylogenic tree. Additionally, MRK05, MRK08 and MRK09 varieties are formed a separate clade whilst MRK10 and MRK11 are closely related to te each other with minimum differences. MRK06 is located significantly distinct in phylogenic tree from the all other breeds analyzed in current work. The sequence information of the $16 \mathrm{~S}$ rRNA gene region as a genetic marker for the differentiation of species is indicated to be potential (Ramadan, 2011). The nucleotide sequences of the haplotypes of the $536 \mathrm{bp}$ fragment of the 16S rRNA gene region of the Morkaraman sheep breed were first reported in this study. (The GenBank database with accession numbers, KU686952.1, KU686953.1, KU686954.1, KU686955.1, KU686956.1, KU686957.1, KU686958.1, KU686959.1, KU686960.1, KU686961.1 and KU686962.1). Sequence information of mitochondrial gene regions is generally used to explain their evolutionary relationships (Meadows et al., 2007; Tapio ve ark., 2006; Resende et al.., 2016). The sequence information of the mtDNA gene regions have also been used in many studies to identify the animal species, rather than sheep, such as poultry (Girish et al., 2007). In particular, the sequence information of the 16S rRNA gene region was also used to investigate the morphological similarity and genetic relationships between bovidae (Kuznetsova et al., 2002). Among Turkish native sheep breeds Tuj (NCBI: HM236183.1) and Karakaş (NCBI: HM236178.1) sheep were also investigated for $16 \mathrm{~S}$ rRNA sequence using Kimura 2 parameters (K2P) model and Neighbor-Joining (NJ) method and resulted trees showed the phylogenetic relationship between the Morkaraman and these animals (Figure 6.). Tuj (HM236183.1) and Karakaş (HM236178.1) did not form separate groups from the Morkaraman varieties but were found to be so close to eachother.

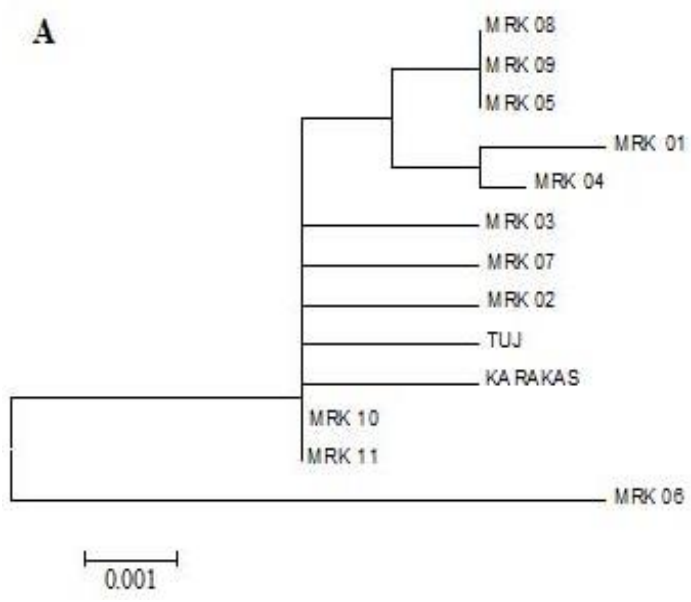

Figure 6. The UPGMA phylogenetic relations the Morkaraman sheep and Turkish native sheep breeds, Tuj and Karakaş sheep.

Findings of current study was also compared with the report of Lv et al. (2015) who studied 4 domestic (Pramenka-Serbia, KarakulMoldova, Swiniarka-Poland and Mountain Carpathian-Ukraine) and 4 commercial sheep breeds (Comisana, Merinizzata Italiana, Lancaune ve Merinos) from Eastern Eurasian and Phylogenetic relationship trees are presented below (Figure 7). 

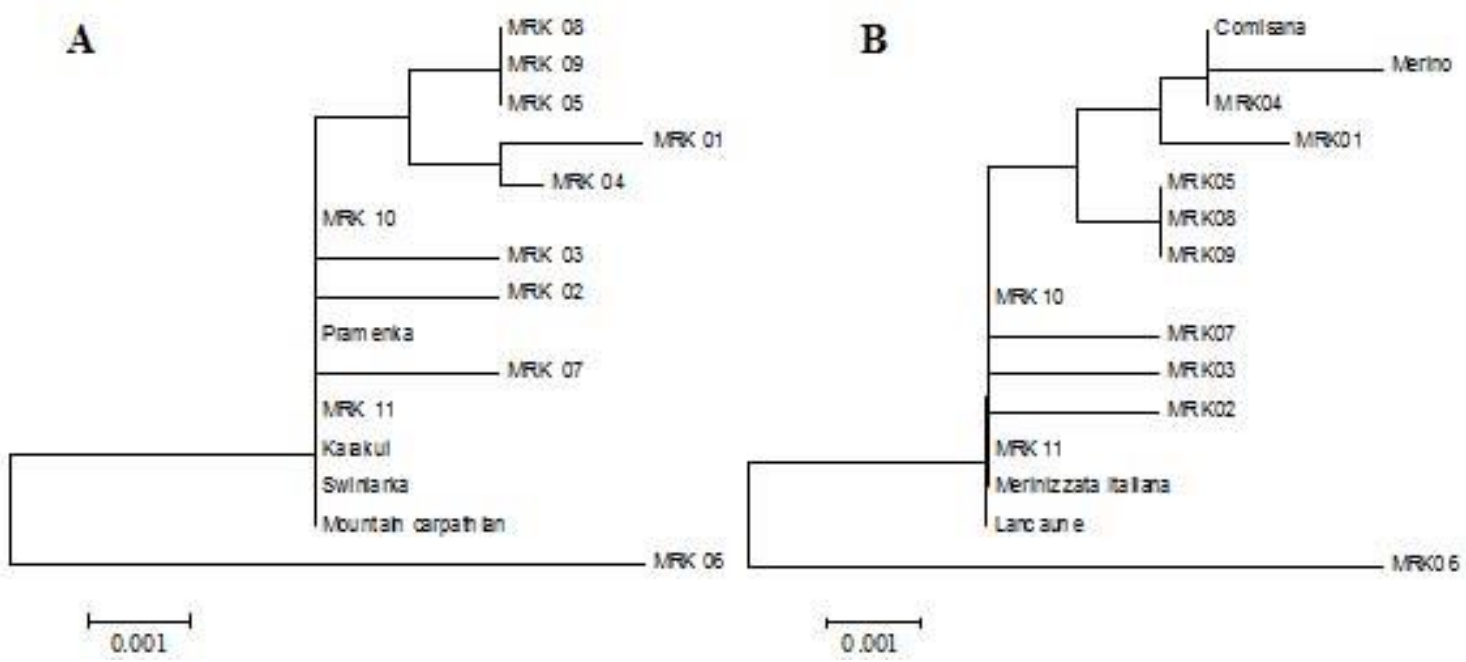

Figure 7. The UPGMA phylogenetic relations the Morkaraman sheep and Eastern Eurasian sheep.

Both trees are shown in the MRK06 seems to be more distinct from the others whilst other haplotypes appear to be claded in Eastern Eurasian sheep.

\section{Conclusions}

Morkaraman sheep constitute an important group of Turkish domestic small ruminants. Especially, it is a small ruminant breed grown in family farms. Research and development of genetic resources and biodiversity of this native bred will be an important issue for conservation of small ruminant livestock of the region. As a result, $16 \mathrm{~S}$ rRNA gene sequences from Morkaraman sheep of Bingöl region were determined. By depositing the gene sequence information in the Gene Bank (NCBI), it is expected to contribute to phylogenetic studies on sheep. In addition, the results of the study are thought to be contributed to genetic polymorphism, biodiversity and animal breeding studies and national gene conservation strategies.

Acknowledgements: The research was supported by the Kahramanmaras Sutcu Imam University for Oğuz AĞYAR's PhD research grant 2016/3-46D "Analysis At The Molecular Level Of Morkaraman Breeds Of Bingol Area". We thank Prof. Dr. Hüseyin NURSOY for their support.

Conflict of Interest Statement: The manuscript's authors declare that, they do not have any conflict of interest.

Researchers' Contribution Rate Statement Summary: The authors declare that, they have contributed equally to the manuscript.

\section{References}

Anonymous.

2020.

TUIK. https://data.tuik.gov.tr/Bulten/Index?p=Ani mal-Production-Statistics-June-2020-33874

Anonymous, 2020.

NCBI. https://www.ncbi.nlm.nih.gov/

Fan, H., Zhao, F., Zhu, C., Li, F., Liu, J., Zhang, L., Wei, C., Du, L. 2016. Complete Mitochondrial Genome Sequences of Chinese Indigenous Sheep with Different Tail Types and an Analysis of Phylogenetic Evolution in Domestic Sheep. AsianAustralasian Journal of Animal Sciences, 29(5), 631-639.

Girish, P. S., Anjaneyulu, A. S. R., Viswas, K. N., Santhosh, F. H., Bhilegaonkar, K. N., Agarwal, R. K., Kondaiah, N., Nagappa, K. 2007. Polymerase chain reaction-restriction fragment length polymorphism of mitochondrial 12S rRNA gene: a simple method for identification of poultry meat species. Veterinary Research Communication, 31 : 447 - 455.

Hiendleder, S., Lewalski, H., Wassmuth, R., Janke, A. 1998. The complete mitochondrial DNA sequence of the domestic sheep (Ovis aries) and comparison with the other major Ovine haplotypes. Journal of Molecular Evolution, $47: 441-448$.

Kimura, M. 1983. "Rarevariant alleles in the light of the neutral theory", Molecular Biology and Evolution 1, 84-93.

Kirikci K., Noce A., Çam, M. A., Mercan, L., Amills, M. 2018. The analysis of mitochondrial data indicates the existence of population substructure in the Karayaka sheep, Small Ruminant Research, 162: 25 - 29

Kul, B. C., Ertugrul, O. 2011. mtDNA diversity and phylogeography of some Turkish native goat 
breeds. Ankara Universitesi Veteriner Fakültesi Dergisi 58(2):129-134.

Kurt, A. O. 2017. Anadolu'da ilk tapınak: Göbeklitepe. Cumhuriyet illahiyat Dergisi, 1107-1138.

Kuznetsova, M. V., Kholodova, M. V., Luschekina, A. A. 2002. Phylogenetic Analysis of Sequences of the $12 \mathrm{~S}$ and $16 \mathrm{~S}$ rRNA Mitochondrial Genes in the Family Bovidae: New Evidence. Russian Journal of Genetics, 38 (8) : 942-950.

Librado, P., Rozas, J. 2009. DnaSP v5: A software for comprehensive analysis of DNA polymorphism data. Bioinformatics, 25: 1451-1452.

Lv, F. H., Peng, W. F., Yang, J., Zhao, Y. X., Li, W. R., Liu, M. J., Ma, Y. H., Zhao, Q. J., Yang, G. L., Wang, F., Li, J. Q., Liu, Y. G., Shen, Z. Q., Zhao, S. G., Hehua, E., Gorkhali, N. A., Vahidi, M. F., Muladno, M., Naqvi, A. N., Tabell, J., Iso-Touru, T., Bruford, M. V., Kantanen, J., Han, J. L., Li, M. H. 2015. Mitogenomic metaanalysis identifies two phases of migration in the history of eastern Eurasian sheep. Molecular Biology and Evolution, 32 (10) : 2515-33.

Mane, B. G., Mendiratta, S. K., Tiwari, A. K., Narayan, R. 2013. Sequence analysis of mitochondrial 16S rRNA gene to identify meat species. Journal of Applied Animal Research, 41 (1) : 77-81.

Meadows, J. R., Cemal, I., Karaca, O., Gootwıne, E., Kijas, J. W. 2007. Five ovine mitochondrial lineages identified from sheep breeds of the near East. Genetics, 175 (3) : 1371-1379.

Naderi, S., Rezaei, H-R, Taberlet, P., Zundel, S., Rafat, S-A, Naghash, H-R, El- Barody, M. A. A., Ertuğrul, O., Pompanon, F. 2007. LargeScale Mitochondrial DNA Analysis of the Domestic Goat Reveals Six Haplogroups with High Diversity. PLoS ONE 2(10): e1012.

Nei, M., Kumar, S. 2000. Molecular evolution and phylogenetics, Oxford University Press, Oxford.

Ramadan, H. A. I. 2011. Sequence of specific mitochondrial 16S rRNA gene fragment from Egyptian buffalo is used as a pattern for discrimination between river buffaloes, cattle, sheep and goats. Molecular Biology Reports, 38 (6) : 3929-3934.

Resende, A., Gonçalves, J., Muigai, A. W. T., Pereira, F. 2016. Mitochondrial DNA variation of domestic sheep (Ovis aries) in Kenya. Animal Genetics, 47, 401-410.

Sambrook, J., Fritsch, E. F., Maniatis, T. Molecular Cloning. 1989. A Laboratory Manual, ed 2.
Cold Spring Harbor, Cold Spring Harbor Laboratory.

Sanna, D., Barbato, M., Hadjisterkotis, E., Cossu, P., Decandia, L., Trova, S., Pirastru, M., Leoni, G. G., Naitana, S., Francalacci, P., Masala, B., Manca, L., Mereu, P. 2015. The First Mitogenome of the Cyprus Mouflon (Ovis gmelini ophion): New Insights into the Phylogeny of the Genus Ovis. PLoS ONE 10 (12): e0144257

Sarri, C., Stamatis, C., Sarafidou, T., Galara, I., Godosopoulos, V., Kolovos, M., Liakou, C., Tastsoglou, S., Mamuris, Z. 2014. A new set of $16 \mathrm{~S}$ rRNA universal primers for identification of animalspecies. Food Control 43, 35-41.

Saikia, D. P., Kalita, D. J., Borah, P., Sharma, S., Barman, N. N., Dutta, R. 2015. Differentiation of sheep and goat speciesby PCR-RFLP of mitochondrial 16s rRNA gene. Journal Animal Research. 5: 213-217.

Saitou, N., Nei, M. 1987. The neighbor-joining method: a new method for reconstruction phylogenetic trees. Molecular Biology and Evolution, 4: 406-425.

Tamura, K., Dudley, J., Nei, M., Kumar, S. 2007. MEGA4: Molecular evolutionary genetics analysis (MEGA) software version 4.0. Molecular Biology and Evolution, 24:15961599.

Tapio, M., Marzanov M., Ozerov M., Cinkulov M., Gonzarenko G., Kiselyova T., Murawski M., Viinalass H., Kantanen J. 2006. Sheep mitochondrial DNA variation in European, Caucasian and Central Asian areas. Molecular Biology and Evolution, 23:17761783.

Togan, İ., Demirci, S., Özkan Ünal, E., Ayanoğlu, ì. C., Parmaksız, A., Dağtaş, N. D., Özer, F., Yüncü, E., Uzun, B., Chiriboga, F., Koban Baştanlar, E., Ergüven, A. 2013. Türkiye'deki Yerli Koyunlarda Genetik Çeşitlilik: Son Sonuçlar, Yeni Sorular. VIth International Balkan Animal Conference BALNIMALCON. 3-5 October 2013. Tekirdag / Turkey.

Yalçın, B. C., 1986. Sheep and Goats in Turkey. FAO Animal Production and Health Paper, No: 60 , Rome, Italy.

Yan, L., She, Y., Elzo, M. A., Zhang, C., Fang, X., Chen, H. 2019. Exploring genetic diversity and phylogenic relationships of Chinese cattle using gene mtDNA 16S rRNA. Archives animal breeding, 62(1), 325-333. 